American Journal of Economics and Business Administration 1 (4): 296-302, 2009

ISSN 1945-5488

(C) 2009 Science Publications

\title{
The Role of Trade Regulations in the Sustainable Management of Natural Resources
}

\author{
Abhijeet Mukherji \\ Faculty of Law, Chatham Lines Campus, University of Allahabad, \\ Allahabad-211002, UP, India
}

\begin{abstract}
Problem statement: The complex issues involved in the role of trade regulations in sustainable management of natural resources have necessitated intensive research in this area. Approach: Hence this study highlights the fact that while the international community is making efforts to take concrete actions to protect the environment, mitigate the negative impacts of increased trade and promote the positive impacts (for example, by integrating environmental considerations into trade policies and international, regional and bilateral trade agreements), some of the most contentious issues affecting international trade involve environmental regulations that become technical barriers to trade (TBT). Although the WTO has the stated objective of-optimal use of the world's resources, sustainable development and environmental protection-the adjudication role of the WTO in trade disputes over environmental regulations as technical barriers to trade has put it adds with some environmental groups. Results: Further, as there are no global environmental standards at present, the trade regulations are having a negative role to play in the sustainable management of natural resources. As a special reference regarding carbon trading, it has been observed in this study that most environmentalists see the Kyoto Protocol as the last best hope to counter global warming. But a growing number of civil society critics point out that the Protocol's "flexible," market-based mechanisms allow corporate polluters to evade their emissions reduction obligations by buying up and trading carbon sinks, also known as carbon assets or carbon offsets. Moreover, the Durban Declaration on Carbon Trading states that "Carbon trading will not contribute to protection of the Earth's climate". It further says that "it is a false solution which entrenches and magnifies social inequalities in many ways". Owing to these complex issues, this research in this area was necessitated. Conclusion: Thus in order to solve such pertinent issues, it has been pointed out that the role of the international trade regime can be an optimistic one towards the sustainable development of natural resources. This problem can be solved by following certain adjudicative and negotiated approaches, but this has to be scientifically, rationally and most importantly, morally backed and must be abided by all the countries of the world for the common interest of protecting their future generations from environmental pollution and its hazards. Moreover, research on this topic also seeks to give certain possible suggestions as to how effectively we can regulate the carbon trading to bring about the sustainable management of natural resources. Thus the implications of this research towards the business and trade regime, if followed, can only be positive, as it would pave the way for a an eco-friendly environment of business which would have sustainability as its essence by inculcating the element of intergenerational equity, so that the aesthetic and economic welfare of the generations that follow is not jeopardized.
\end{abstract}

Key words: Trade regulations, sustainable management, natural resources

\section{INTRODUCTION}

The international community is making efforts to take concrete actions to protect the environment, mitigate the negative impacts of increased trade and promote the positive impacts. One example is by integrating environmental considerations into trade policies and international, regional and bilateral trade agreements. However, it is important to ensure that internalizing environmental costs does not adversely affect market access and it is important that this does not act as unfair obstacle to trade or are protectionist in intent, but also that trade rules do not discourage environmental protection.

Background: Some of the most contentious issues affecting international trade involve environmental regulations that become technical barriers to trade 
(TBT). However, international agreements that control trade and the flow of global financing can be expected to have a major impact on sustainable development.

Although the WTO has the stated objective ofoptimal use of the world's resources, sustainable development and environmental protection-the adjudication role of the WTO in trade disputes over environmental regulations as technical barriers to trade has put it at odds with some environmental groups ${ }^{[1]}$. One example was the revision of clean air regulations in the US to allow import of dirtier gasoline. At the WTO meeting in Doha, the WTO reaffirmed its commitment to sustainable development ${ }^{[2]}$. The preamble of the Marrakesh agreement, which established the WTO, specifically addresses sustainable development ${ }^{[3]}$. General Agreement on Tariff and Trade (GATT) article 20 allows countries to protect their environment but actions must be reasonable and not protectionist $^{[4]}$. A good case can me made that trade is necessary for sustainable economic development and at about the same time as the meeting in Seattle, the WTO and the United Nations Environmental Program (UNEP) announced that they had agreed to work together in areas of mutual interest to achieve the aims of the Rio declaration ${ }^{[5]}$.

There is no world environmental organization and the United Nations has no authority to set environmental standards. Treaties come closest to actually setting global environmental standards. Another situation is when large trading entities such as the United States and the European Union (EU) agree on environmental standards. Vogel ${ }^{[6]}$ states that when this happens, these standards become, in fact, global standards.

The existing problem: Although there is concern that different environmental standards could lead to trade imbalances, there are many good reasons why environmental standards could be different in different countries. Even in the US there can be frustration with one-size-fits-all environmental regulations and there is considerable flexibility to set state and local environmental regulations affecting construction and to a lesser extent manufacturing.

In addition to moving more regulatory oversight to the states, the trend toward businesses solving their own environmental problems and sharing good practices with others is evolving. Globally, the United Nations Environmental Program (UNEP) is encouraging businesses to solve their environmental problems. Businesses are working together to promote sustainable development and better environmental management though the World Business Council on Sustainable
Development (WBCSD) and now the United States business council for sustainable development.

The present position: As there are no global environmental standards at present, the trade regulations are having a negative role to play in the sustainable management of natural resources. However, the role of the international trade regime can be an optimistic one towards the sustainable development of natural resources and this problem can be solved by following certain adjudicative and negotiated approaches, but this has to be scientifically, rationally and most importantly, morally backed and must be abided by all the countries of the world for the common interest of protecting their future generations from environmental pollution and its hazards.

Solutions to the problem: For the proper sustainable management of natural resources it is imperative that WTO in general and trade regulations in particular should play a vital and effective role to usher in a positive change in the present scenario. Given below are certain solutions in this regard.

Adjudicative approaches: Interpretation of existing trade rules through WTO dispute settlement: Since its creation in 1995, the WTO appellate body has somewhat helped quell the antagonism between the trade and environmental regimes. However, given the lack of political will among States to negotiate solutions to the many questions that remain unanswered about the compatibility of the trade and environmental regimes, it is likely that these issues will continue to be resolved on an ad hoc, case-by-case basis as they arise, through interpretation and application of the existing WTO rules within the WTO dispute settlement system.

One way to address trade-and-environment disputes would be for the WTO dispute settlement process to interpret the article XX GATT 1994 exceptions to allow more environmental rules to meet the tests of $\mathrm{XX}(\mathrm{b}), \mathrm{XX}(\mathrm{g})$ and the chapeau-including by taking greater account of emerging principles of international environmental law such as the precautionary principle and the polluter-pays principle ${ }^{[8]}$. The WTO appellate body has already started down this road, through its reference to the developing corpus of international environmental law in interpreting the phase 'exhaustible natural resources' in article $\mathrm{XX}(\mathrm{g}){ }^{[9]}$ its statement that general principles of international law can provide 'interpretive guidance' with respect to the article XX chapeau and its more relaxed reading of 'necessity' in article $\mathrm{XX}(\mathrm{b})$ and "related to" in article $\mathrm{XX}(\mathrm{g})^{[10]}$. 
Additional steps might include the following:

- Article XX $(\mathrm{g})$ could be read to allow countries to adopt unilateral measures to protect the environment outside of their national borders (possibly even within the national territories of other States)

- The status of MEAs could be clarified, through a per se rule that multilateral environmental measures satisfy the requirements of the article XX chapeau (though this would raise further issues about the number of parties necessary to qualify an agreement as 'multilateral')

Moreover, panels and the appellate body could apply the principles of general international law regarding treaties to clarify the relationship between the WTO covered agreements and MEAs.

Some scholars have suggested that an MEA requiring trade sanctions should prevail over any contrary WTO rule as an inter se agreement ${ }^{[11,12]}$. However, obvious problems would arise if such sanctions were applied against non-parties of the MEA. Alternatively, some have suggested that MEA rules addressing trans-boundary externalities should prevail because, as the ICJ stated in the nuclear weapons decision, 'the general obligation of States to ensure that activities within their jurisdiction and control respect the environment of other States or of areas beyond national control is now part of the corpus of international law relating to the environment ${ }^{[13]}$.

Creating a more neutral forum for dispute resolution: The appellate body's willingness in USShrimp to accept an amicus brief field by an environmental NGO and its ultimate decision upholding the US import ban, have helped reduce the perception that the WTO dispute settlement system does not provide a fair forum for addressing trade-andenvironment disputes ${ }^{[14]}$. As critics of the current system note, panelists and Appellate Body Members are generally drawn from the trade community and, in the view of critics, give too little weight to environmental issues when making decisions ${ }^{[15]}$. This lack of environmental expertise is compounded by the fact that the hearings are closed to the public-and therefore NGOs and public interest groups-unless otherwise agreed by the parties involved.

There are several alternative fora that could hear trade/environmental disputes. The ICJ, for example, has an as yet unused chamber for environmental matters and the Permanent Court of Arbitration (PCA) has established a set of rules for the arbitration of environmental disputes.

As a result, what is needed, some argue, is a dedicated international environmental court that could adjudicate environment and trade issues. Potential benefits of a new environmental court include a more balanced composition, greater openness and transparency, recognition of standing for individuals and NGOs in cases where national remedies have been exhausted and recognition of the common interest of human kind of protecting the global environment ${ }^{[16]}$.

The choice of a forum for resolving tradeenvironment disputes will ultimately have to be decided on the grounds of strategic and policy considerations relating to ethos and expertise and rules regarding access and participation.

Negotiated approaches: Typically, States prefer to address international issues through negotiation rather than adjudication, since this allows them to keep greater control over the ultimate outcomes. When the WTO was initially created, its Members appeared ready to address trade-and-environment issues through a negotiated, political process and they have continued to include environmental issues in the mandate of the current Doha Round of negotiations ${ }^{[17]}$.

Amendment of the trade regime: Rather than rely on WTO dispute settlement, WTO members could undertake negotiations within the WTO to resolve the outstanding issues regarding the compatibility of environmental measures with free trade.

Negotiations could also address the permissibility of PPM standards, such as a carbon tax on electricity or eco-labeling requirements, as well as the permissibility of precautionary measures to address potential harms about which there exists little scientific evidence.

Development of common environmental standards through a global environmental organization: A host of scholars and policymakers have proposed that some type of Global Environmental Organization (GEO) or World Environmental Organization (WEO) be established to counterbalance the WTO and address international market failures that result in environmental harms ${ }^{[18-20]}$. In broad strokes, the GEO might, inter alia, work to centralize the environmental regime under one institutional umbrella, coordinate the current mass of MEAs, discipline violators, create new policy, disseminate information and conduct research and fulfill environmental support and advocacy functions at the WTO. Moreover, the GEO could develop common international environmental standards 
to replace national standards that hinder trade, in much the same way that the federal government establishes uniform environmental rules within the US federal system $^{[21]}$.

Many environmentalists have lent support to this idea in the hope that centralization might empower the international environmental regime and allow it to stand up to the WTO, or at least better moderate the tradeenvironment debate. Some free trade advocates have also come out as per-GEO, betting that the creation of a strong environmental organization would help bridge the gap between trade and environment and might steer countries away from the 'inappropriate' use of trade measures $^{[22]}$.

The solutions discussed above are perhaps the best of an imperfect set of alternatives.

Role of carbon trading in sustainable management of natural resources: A special reference: Most environmentalists see the Kyoto protocol as the last best hope to counter global warming. But a growing number of civil society critics point out that the Protocol's "flexible," market-based mechanisms allow corporate polluters to evade their emissions reduction obligations by buying up and trading carbon sinks, also known as carbon assets or carbon offsets.

This new trade is part of the emerging market in "environmental services", which supporters claim can harness market forces and private property to provide economic incentives for environmental protection. But some environmentalists and indigenous peoples warn that this trade signals a new wave of enclosure and privatization of natural resources. They claim it has plenty to do with making money and nothing to do with saving the environment.

Contrary to popular belief, the Kyoto protocol does not commit industrialized countries to any substantial cuts in their emissions of carbon-based pollutants that cause the greenhouse effect. It commits them to reduce them to $5.2 \%$ below 1990 levels by 2008-2012, a far cry from what climate experts say is necessary to avert a planetary catastrophe. According to the intergovernmental panel on climate change, global emissions must be reduced to at least $60 \%$ below 1990 levels. And even the modest $5.2 \%$ reductions might not be achieved on schedule due to numerous loopholes built into the protocol itself.

Under the protocol, the UN would distribute pollution rights to 38 industrialized nations. With the exception of the United States, which is boycotting the Protocol, these governments are quietly handing out these entitlements free of charge to major corporate polluters in sectors like electricity generation, oil, steel, cement, chemicals, pulp and paper. These pollution rights are tradable, much to the joy of free market advocates and consternation of environmental critics.

"The distribution of carbon allowances constitutes one of the largest, if not the largest, projects for creation and regressive distribution of property rights in human history", said Larry Lohman of the UK-based activist group The Cornerhouse.

Under the protocol's clean development mechanism, a corporation can buy a carbon sink in the global South to offset its own emissions. A carbon sink is anything that keeps greenhouse gases out of the atmosphere either by preventing their release or by sequestering them. Forests and tree plantations are the preferred sink, since trees remove carbon from the atmosphere and sequester it in their wood. Renewable energy projects are also admissible as sinks since they produce energy without burning fossil fuels.

The trade in pollution rights and carbon sinks has spawned a new form of commerce whose players include major corporations, universities, think tanks, eco-consultants, forestry industries, the World Bank ${ }^{[7]}$, UN agencies, specialized carbon brokers like Future Forests, Natsource and eco-securities and some environmental groups like the world resources institute and environmental defense.

The carbon trade's supporters claim it is a "winwin" solution that offsets polluting emissions while providing badly needed funds for sustainable development and forest conservation in the South.

"Companies can supplement their commitments at home by purchasing potentially lower-cost emission reductions in developing countries", states the World Bank's Prototype Carbon Fund (PCF) at its website. "As a result, projects in these countries will get a new source of financing for sustainable development in the energy, industrial and waste management sectors, land rehabilitation and in the introduction of clean and renewable technologies. The PCF has played a pioneering role in developing the market for greenhouse gas emission reductions, while promoting sustainable development and offering a learning by doing opportunity to its stakeholders".

"This challenge is creating a new opportunity for low-income farmers and rural communities to get paid by industrialized countries for growing trees that will absorb carbon from the atmosphere (carbon offsets)". says the Katoomba Group, a business organization that promotes carbon markets. "These new markets for forest carbon offsets can finance rural development investments that help to reduce poverty and conserve biodiversity. The world's poor have much to gain from participating in forest carbon projects that improve farm 
and forest production, protect critical watersheds, or restore degraded lands and forests".

"Sequestration of atmospheric carbon through afforestation and reforestation can be achieved through a wide range of land use changes, including many changes that can significantly improve rural livelihoods and restore degraded ecosystems", said an open letter addressed to UN climate change convention delegates, signed by over a dozen personalities, including former Costa Rican president and world economic forum CEO Jose M. Figures as well as Pedro Sanchez and M.S. Swaminathan, both laureates of the World Food Prize. "Well designed carbon projects can help local people to invest in more sustainable and profitable land and forest management systems, restore degraded ecosystems, build natural assets and strengthen community organizations".

Critical voices: "Carbon trading will not contribute to protection of the Earth's climate", states the Durban Declaration on Carbon Trading". It is a false solution which entrenches and magnifies social inequalities in many ways".

The declaration was issued in October 2004 by representatives of people's movements and nongovernmental organizations who met in Durban, South Africa. The signatories include organizations from Samoa, India, Brazil, the Indigenous Environmental Network, the UK-based Sinkswatch and the US-based global justice ecology project.

The document points out that the carbon trade's players include the very culprits of global warming and denounces that these same institutions are using the environmental crisis they themselves caused as a rationale to evade real reductions in emissions and appropriate for themselves more natural resources.

Using monoculture tree plantations as carbon sinks has especially pernicious effects, according to environmentalists-they assert that the plantations eliminate biodiversity and destroy regional ecosystems. "The idea of carbon sinks is unrealistic and the pretense that tree plantations may in any way is a solution is being challenged", said Ricardo Carrere, director of the Uruguay-based World Rainforest Movement (WRM).

Several environmental groups in Latin America are beginning to take notice of the carbon trade and warn of its consequences.

"The real solution is the conservation of energy, the reduction of consumption, a more equitable use of resources and equitable development and distribution of clean and renewable low impact energy sources," declared the WRM in 2004 in response to claim made by self-proclaimed carbon brokers. "Yet, while it is almost a platitude to say so, the political will of governments will be necessary. This is scarce and when it does exist, it must face very powerful and implacable interests".

Probable solutions for effective regulation of carbon trading: In order to bring about the sustainable management of natural resources the following three solutions are suggested below:

- In a 2005 report, the international environmental group friends of the earth recommended the following alternatives to the carbon trade

- Encourage discussion and negotiation about all the possible ways of dividing up existing carbon dump space equally, including ones that do not involve tradable private property

- Work toward keeping remaining fossil fuels in the ground, for example by:

- Supporting and linking existing movements (against oil drilling, for example), setting their areas off limits to mining, drilling and power production

- Supporting energy efficiency, renewable, nonfossil-fuelled technologies and responsible tree-planting, but without trading them for continued fossil fuel extraction

- Regulation, taxation and other measures that do not start with an assumption that corporations already own the world's carboncycling capacity

- Responsibility is to be enforced on larger countries regarding the arbitrary carbon trading. Unless China and India can be induced to take a lower carbon path than the west, there is absolutely no hope

- Further, we need to crank down the global supply of fossil fuels. This is much simpler and more effective than trying to cap emissions, an almost hopeless task. In this regard Kyoto2 shows how this can be effected. The writer of this book Oliver Tickell has really provided a fresh accessible, cogent and bold case for a radical departure from most established thinking. Very seldom is an argument made with such gusto, sharpness and wisdom. It has been rightly stated that "whether you agree with Oliver Tickell or not, your understanding of and thinking about this vital global challenge will be greatly enhanced" ${ }^{[23]}$

Tickell ${ }^{[23]}$ hits the nail on the head by showing how to work effectively to achieve a level of atmospheric 
$\mathrm{CO}_{2}$ below 350ppm. At the heart of the proposal is a global trade in carbon with a series of reducing caps sufficiently rigorous to bring about such an outcome.

\section{CONCLUSION}

Intergenerational equity is among the newest norms of international environmental law. It can best be understood not so much as a principle, but rather as an argument in favor of sustainable economic development and natural resource and its use. If present generations continue to consume and deplete resources at unsustainable rates, future generations will suffer the environmental (and economic) consequences. Therefore, we must all undertake to pass on to future generations an environment as intact as the one we inherited from the previous generation.

Proponents of intergenerational equity maintain that the present generation has a moral obligation to manage the earth in a manner that will not jeopardize the aesthetic and economic welfare of the generations that follow. From this moral premise flow certain ecological commandments: 'Do not cut down trees faster than they grow back. Do not farm land at levels, or in a manner, that reduce the land's regenerative capacity. Do not pollute water at levels that exceed its natural purification capacity'.

Thus it may be concluded that the trade and environmental regimes are two of the most dynamic in all the international law. That they have bumped up against one another from time to time, as they grow in scope and depth, should not be surprising. Managing (and, when possible, avoiding) their potential conflicts and exploiting their potential synergies, will pose a continuing challenge. Already, each regime has shown greater sensitivity to the other. The jurisprudence of the appellate body evidences a greater willingness to take into account environmental values and environmental regimes have become more restrained in their use of trade measures for environmental purposes. This shows that there would be a positive role of trade regulations in the sustainable management of natural resources in future provided they are followed in letter and spirit.

\section{REFERENCES}

1. von Bogdandy, A., 2006. WTO-Institutions and Dispute Settlement. Martinus Nijhoff, Leiden, pp: 17. http://edoc.mpg.de/302274

2. Word Trade Organization, 2001. Doha Ministerial Declaration. http://www.wto.org/english/thewto_e/minist e/min01_e/mindecl_e.htm
3. Word Trade Organization, 1994. (WTO) Marrakesh Agreement establishing the World Trade Organization and Final Act. http://en.io.gov.mo/Legis/International/record/179. aspx

4. General Agreement on Tariffs and Trade, 1988. Canada-restrictions on exports of unprocessed herring and salmon. Report of the Panel, BISD 35/S/98-115, GATT, Geneva.

5. World Trade Organization, 2007. Existing forms of cooperation and information exchange between UNEP/MEAs and the WTO. http://www.unep.org/gc/gc24/docs/s2r2.finaldoc.pdf

6. Vogel, D., 1997 Barriers or Benefits?: Regulations in Transatlantic Trade. Brookings Institution Press, Washington DC., pp: 80.

7. World Bank, 1999. Greening Industry: New Rules for Communities, Markets and Governments. Oxford University Press, New York.

8. Barral, W., 2007. Reforming the DSU. In: Trade and Environment: A Resource Book, Najam, A. et al. (Eds.). International Institute for Sustainable Development, Geneva.

9. World Trade Organization, 1998. United States Import Prohibition of Certain Shrimp and Shrimp Products. WT/DS58/R, Report of the Panel. http://www.sice.oas.org/DISPUTE/wto/58r00/shriu s.asp

10. Van Damme, I., 2008. Appellate Body Report, Brazil: Measures Affecting Imports of Retreaded Tyres, Adopted on 17 December 2007. Int. Comparat. Law Q., 57: 710-723. http://www.jstor.org/pss/20488240

11. Petersmann, E.U., 1995. International and European Trade and Environmental Law after the Uruguay Round. Kluwer Law International, London, pp: 168.

12. Pauwelyn, I., 2003. Conflict of Norms in Public International Law: How WTO Law Relates to Other Rules of International Law. Cambridge University Press, Cambridge, pp: 572.

13. International Court of Justice, (ITC), 1996. Legality of the threat or use of nuclear weapons. Advisory Opinion, ICJ Reports. http://www.fas.org/nuke/control/icj/text/9623.htm

14. Scott, J., 2007. The WTO Agreement on Sanitary and Phytosanitary Standards: A Commentary. Oxford University Press, Oxford, pp: 400.

15. Lang, W., 1996. WTO Dispute Settlement: What the Future Holds. In: Asian Dragons and Green Trade: Environment, Economics and International Law, Tay, S.S.C. and D.C. Esty (Eds.). Times Academic Press, Singapore, pp: 145. 
16. McCallion, K.F. and H.R. Sharma, 2000. Environmental justice without borders: The need for an international court of the environment to protect fundamental environmental rights. George Washington J. Int. Law Econ., 32: 359-65.

17. Yu, V.P.B., 2001.Trade and Environment in the Doha Ministerial Declaration: Looking at Paragraphs 6 and 31 to 33 of the Doha Ministerial Declaration.

http://tradeobservatory.org/library.cfm?refID $=25554$

18. Charnovitz, S., 2002. A world environment organization. Columbia J. Environ. Law 27: 323-26.

19. Kennan, G.F., 1970. To prevent a world wasteland: A proposal. Foreign Affairs, 48: 411-412.
22. Biermann, F., 2000. The case for a world environment organization. Environment, 42: 22-31.

21. Stewart, R.B., 1992. International trade and environment: Lessons from the federal experience. Washington Lee Law Rev., 49: 1329-1337.

22. Ruggiero, R., 1999. Opening remarks to the high level symposium on trade and the environment. http://www.wto.org/english/tratop_e/devel_e/hlstat _e.htm

23. Tickell, O., 2008. Kyoto 2: How to Manage the Global Greenhouse. Zed Publications, ISBN: 9781848130241 . 